\title{
Study Von Savigny's Thinking About Morals in Law: Understanding Moral in the Concept of Law “Barenti Lako Syara' Tradition, Syara Barenti Lako Kitabullah"
}

\author{
Dianto \\ Institut IImu Sosial dan IImu Budaya Samawa Rea \\ diantosubiyanto@gmail.com
}

DOI: $10.23917 / j t l . v 2 i 1.11247$

\section{Submission \\ Track:}

Received:

21 June 2020

Final Revision:

4 July 2020

Available online:

31 July 2020

Corresponding

Author:

Dianto

diantosubiyanto@gmail.com

\begin{abstract}
Objective: This article aims to discuss moral boundaries in the Law According to Von Savigny and moral limits in the Law According to the Legal Concept Principles of "Barenti Lako Syara' Tradition, syara barenti ko kitabullah"

Methodology: The methodology used in this study is normative juridical research. This study uses a philosophical approach by exploring the philosophical basis of Law by linking legal science with the concept of customary Law.
\end{abstract}

Findings: Von Savigny does not limit the moral meaning in Law whether good or bad, wrong or right, depends on morals in the habits of society that are not separate from morals and facts. Meanwhile, tau samawa based on the legal concept of "barenti lako syara' tradition, sara barenti lako Kitabullah" means moral boundaries in Law, morals can be accepted into Law after the validation process with the book.

Application of the Study: Customary Law has an indicator of moral constraints, so that applicable Law in general can also have indicators of moral limitations as customary Law.

Originality/Novelty: Syara' becomes a verification tool for morals in the customary Law of tau samawa and the book of Allah becomes a moral detector in the syara'

Keywords: Moral, Law, tradition, syara'

\section{INTRODUCTION}

Von Savigny's thought that "the Law must be seen as an incarnation of the soul or spirit of a nation. There is always a relationship between Law and personality of a 
nation" (volkgeist). ${ }^{1}$ Volkgeist is manifested in the form of language, customs, culture, habits, traditions, beliefs of people. According to Herman, volkgeist is a manifestation of the spirit of a society and at the same time becomes the life of that community. ${ }^{2}$ Savigny sees Law as a cultural product that flows with the flow of time/history. The Law always develops with the people/nation. Therefore, the Law in the school of history guarantees its validity empirically. The creation of Law is formed naturally by Values as a cultural formation born from the communal consciousness of the people/the soul of the nation (Volksgeist) which has always been maintained for a long time and has become a historical fact. One source of Savigny's volkgeist is moral which is part of the Law itself.

Thomas Aquinas placed morals above the Law, Jhon Austin put the laws and morals separately, Hart positioned the Law as a minimum requirement for the formation of the Law to try to eliminate the legal rigidity of the classical positivism Austin and Von Savigny positioned morals as part of the Law itself. Tamanaha places legal relations with the community in a tripartite relationship, namely (a) custom/agreement; (b) morals and reason; and (c) positive $\mathrm{Law}^{3}$

Hart reveals the Law and morality. First, how to distinguish between moral ideas in justice and justice in Law. Second, how to distinguish between moral rules and legal rules from all other social rules. And third, various components that explain that Law and morality continue to have a relationship. ${ }^{4}$ The prophetic paradigm view is based on the epistemological assumption that relative morality is the result of creation and the will of absolute reality and norms of morality, that is, reality should be created on the will of the authorities through a messenger, with epistemological values/ethos in the form of a combination of community reality and values of authority. ${ }^{5}$

Von Savigny did not limit the intention of "habits" that were made into Law whether they were restricted to good or bad habits so that the morals meant by Savigny were dependent on the habits of the community itself. For example, the custom of slavery that is universal in society. Slavery is the will of the ruler, not the universal will of society. In the view of Muslim societies there are limits to every habit prevailing in

${ }^{1}$ Abdul Wahid dan Anang Sulistyono, Etika Profesi hukum dan Nuansa Tantangan Profesi Hukum Di Indonesia, Panduan Bagi: Penasehat Hukum, Hakim, Jaksa, Polisi, dan Mahasiswa Fakultas hukum, Penerbit:Tarsita Bandung, 1997. Hal. 7

${ }^{2}$ Anonim. Friedrich Von Savigny: Padjadjaran: Jurnal Ilmu Hukum Volume 2 Nomor 1Tahun 2015 Hal. 199 Press.hal. 4

${ }^{3}$ Brian Z Tamanaha,. 2006. A General Jurisprudence for Law and Society. New York: Oxford University

${ }^{4}$ Fitrah Hamdani, PARADIGMA PROFETIK: Antara Konsep Moralitas Piagam Madinah dan Konsep Moralitas Hukum H.L.A. Hart. Jurisprudence, Vol. 6 No. 1 Maret 2016 Hal. 64

${ }^{5}$ Khuzaifah Dimyanti, Absori, kelik Wardiono, Fitrah Hamdani, : Morality anda law: Critics Upan H.L.A Hart'S Moral Paradigm Epistemology Basis based on Prophetic Paradigm. Jurnal Dinamika Hukum. Volume 7 Nomor 1 Tahun Januari 2017 
society both the boundary between good and bad and the boundary between halal and haram. Likewise the opinion of Tau Samawa is based on the legal concept of "barenti lako syara' tradition, syara' barenti lako Kitabullah" that custom or becoming Law can be accepted when it has been validated by the book of Allah and as-sunnah.

The problems to be deciphered in this article, first, examine the meaning of moral boundaries in Law according to Von Savigny and, second, examine moral boundaries in Law according to Tau Samawa based on the legal concept of "barenti lako syara' tradition, syara' barenti lako Kitabullah".

\section{RESEARCH METHOD}

In this study the authors used normative juridical research. This study uses a philosophical approach by exploring the philosophical basis of legal science by linking legal science with the legal concept of "barenti lako syara' tradition, syara' barenti lako Kitabullah". This is intended to strengthen the basic philosophy of the development of the science of Law pioneered by Von Savigny who states that Law is a public habit (volkgeist).

\section{RESULTS AND DISCUSSION}

\section{A. Moral Restrictions in Law According to Von Savigny}

Savigny's thoughts about Law were imbued by the romanticism movement. This movement is a movement against the enlightenment that idolizes ratios or reason and universal concepts. 'This movement emphasizes feelings, worldly aspects (transcending worldly), folklore (legendary, mythical), fantasy, religiosity in countering rationalism, and the spirit of the Enlightenment, which overemphasizes the function of individuals as Subjected Subjects'. ${ }^{6}$

Von Savigny considered the Law as the soul of the nation (volkgeist), which originated from the customs, morals, ethics, habits of the people. He called the Volkgeist, 'unique, supreme, and mystical reality' so that it was not understood rationally but was perceived intuitively. ${ }^{7}$ The soul of the nation places "the Law is something that is supra-individual, a symptom of society. But society is born in history" $"$

\footnotetext{
${ }^{6}$ Antonins Cahyade. HUKUM RAKYAT Ii La Friedrich Karl von Savignyl JurnaJ Hukum dan Pembangunan, Tahun Ke-35 No.4 Oktober-Desember 2005. Hal. 392

${ }^{7}$ Widodo Dwi Putro, Perselisihan Sociological Jurisprudence dengan Mazhab Sejarah dalam Kasus "MERARIK" Kajian Putusan Nomor 232/Pid.B/2008/PN.Pra, Jurnal Yudisial Vol. 6 No. 1 April 2013, hal. 57.

${ }^{8}$ Lovell, T (ed.). 2007. (Mis)recognition, Social Inequality and Social Justice: Nancy Fraser and Pierre Bourdieu. London and NewYork: Routledge. Lovell, 2007: 2-3).
} 
The role of the state, according to this group, is to process and articulate the spirit of the nation or the absolute spirit (Volksgeist) into the existing functions of the state, both in the form of the executive and legislative branches.

Positive Law, from the perspective of historical guidance, is consciousness. Positive meaning has a context of shared existence and is surrounded by the souls of the people (nation) who are bound in time and space. The meaning of positive words in historical guidance is substantial, not formal. According to Savigny, positive Law is a law that lives and arises in a society, in the form of general awareness of the people. Legislation institutions in a country are seen as part of the positive legal organs that exist. The legislative institution is the way to actualize positive Law in the legislative process. The role of legislation in affirming the role of positive Law becomes so important as an articulation of the will of the people to achieve legal certainty and justice. ${ }^{9}$

The historical guideline views that Law is possible for the occurrence of legal unification because the Law can be formatted in legislation and legal science institutions, then it becomes positive Law, which is actualized in writing. Savigny put the role of Judge as an articulator/seeker of legal values living in the community. For this reason, judges must engage in the community to recognize, feel, and be able to know the legal feelings and a sense of justice that exists in the community.

Von Savigny explains his guidance, revealing that the Law is something natural, innate, not formed, created, but grows by itself. He considered that on this earth, there are many districts that have different volumes so that the Law only applies within the district based on time and place. Volksgeist "is not designed, born naturally as a biological heritage of people." 10

Savigny's assertion that in every nation there is a volkgeist of each, which in the context of Indonesia consists of many ethnic groups who have different customs, cultures, morals, show that morality in Law depends on the prevailing morals in society. For example, in Java, Sumatra, Mbojo, Sasak, the morals prevailing in these tribes. Likewise, in a strong ethnic group with the belief or understanding of hedonism that does not limit moral meaning. "Therefore, good or bad, ethical or unethical measures of hal. $124-128$

${ }^{9}$ Von Savigny dalam Antonius Cahyadi dan Fernando M. Manullang, Pengantar Filsafat Hukum, 2010;

${ }^{10}$ MDA Llyod Freeman. 2001. Introduction to Jurisprudence. London: Sweet Maxwell. Hal, 905 
action are always based on an enjoyment goal." 11 Morals are formed from theology or religion, as explained in Genesis or 1:28 that teaches: ${ }^{12}$

"So that humans develop well and rule the earth conquer and dominate fish in the sea and birds in the air and conquer all living things' ${ }^{13}$ "God blessed them [humans], saying to them: 'Be fruitful, multiply, fill the earth and conquer [subdue] it. Be masters of the fish of the sea, the birds of heaven and all living animals on the earth." (Genesis, 1:28). Another verse in Genesis 1:27 that encourages the supposition of humans to be superior to other creatures. Humans are given the mandate to control Nature and all of its contents. This spirit has two major implications, namely the entire contents of Nature and the ecosystems in it that encourage humans to master it and place humans as superior elements above other creatures.

Volkgeist as Savigny's Law is not morally restricted even though his ethical morals are in the form of hedonism, pragmatic, materialistic, and even moral is supported by certain beliefs. An example of the strength of the volkgeist in the Padukuhan Talonang West Sumbawa indigenous people is that the regional head cannot issue a plantation business permit without regard to local customary Law as stated by Dianto in his research that "there is no requirement for the authority of the regional head to issue a plantation business permit in a customary forest, there is no regulation regarding the release of forest areas to customary forests used by plantation business land and juridical consequences for each plantation business permit issued not based on the decision of the Constitutional Court No. 35/PUU-X/2012 is null and void"14.

In the Indonesian context, Volkgeist is seen in indigenous peoples who are recognized through the constitution and in areas recognized by regional regulations or Regional Head Decree. Charles Taylor, in Dianto's writing, about the politics of recognition that was philosophically inspired by Hegel and Honneth. Initially, the politics of recognition departs from philosophical, cultural, and identity politics studies. A prominent philosophical study of recognition was proposed by Hegel. ${ }^{15}$

\footnotetext{
${ }^{11}$ Absori, Khudzaifah Dimyati, Ridwan. Makna Pengelolaan Lingkungan Pespektif Etik Profetik , AlTahrir, Vol. 17, No. 2 November 2017 Hal. 337

12 Ibid. 335

${ }^{13}$ Ibid.

${ }^{14}$ Dianto, Kewenangan Kepala Daerah Menerbitkan Izin Usaha Perkebunan Di Hutan Adat, Jurnal IUS | Vol III | Nomor 8 | Agustus; 2015 | hlm, 234 IUS Kajian Hukum dan Keadilan hal. 232

15 Dianto, Pola Penyelesaian Konflik Rekognisi Hak Masyarakat Adat Di Kabupaten Sumbawa Equilibrium: Jurnal Pendidikan Vol. VIII. Issu 1. Januari-Juni 2020. Hal 60
} 
B. Moral Restrictions in Law According to the Legal Concept Principles of "Barenti Lako Syara' tradition, Syara' barenti ko kitabullah"

\section{The Philosophical Meaning of Barenti Lako Syara', Syara'Barenti Lako Kitabullah}

Sumbawa Regency is located on Sumbawa Island, West Nusa Tenggara. The number of indigenous people (Samawa ethnic) is $68.66 \%$, and the rest comes from the Mbojo, Sasak, Balinese, Bugis, Makassar, Minang, Sumba, Arabic tribes. ${ }^{16}$ The Tau and Tana' Samawa Guidelines is "Barenti Lako Syara' tradition, Syara' Barenti Lako Kitabullah." Philosophy of “Barenti Lako Syara' Tradition, Syara' Barenti Lako Kitabullah" is a value as a foothold to behave Tau to Tana'Samawa. The basis for acting and behaving Tau Samawa 'Barenti Lako Syara' tradition, Syara' Barenti Lako Kitabullah" has gone through the process of a series of historical societies to find community agreements as a way of life, a law that applies to the Tau Samawa community.

The agreement in history was shown since Islam was known by the Sumbawa community, namely a hormonal meeting between customary Law and the concept of Islam being a law consisting of values and norms in the Sumbawa community. The agreement is that there is a degree of adat that is verified by the Islamic concept. Indicators of tradition can be accepted if they are not in conflict with the Islamic concept. Agreement as a result of the approval becomes a natural law, or we often call it sunnatullah.

The harmony meeting between tradition and religion is a spiritual collaboration of the truth of local wisdom (tradition) with religious truth or the same collaboration between "ratio" with "revelation". In the context of philosophy, the meeting of harmony is part of the epistemology in philosophy. The study of philosophy by looking at the tradition, which is a legal behavior of the community,

${ }^{16}$ Syaifuddin Iskandar, Konflik Etnis samawa dengan etnis Bali dalam konstruksi sosial masyarakat sumbawa. Disertasi. 2013. Hal. 1 
is part to "study philosophical issues arising from the existence and practice of law'. ${ }^{17}$

Ontologically, the philosophical value is strong in "Barenti Lako Syara' Tradition, Syara' Barenti Lako Kitabullah", the truth that is recognized by Tau Samawa - in epistemology, seeing the Sumbawa people who are tolerant, open, moderate due to the meeting of harmony and harmony with the existence of tradition and shari'a which are recognized by Tau Samawa as a truth that is complementary, mutually reinforcing, mutually supportive.

2. Moral in Law According to the Legal Concept of "Barenti Lako Syara' Tradition, Syara' Barenti Lako Kitabullah".

The Sumbawa people are guided by “Barenti Lako Syara’ Tradition, Syara” Barenti Lako Kitabullah" as the basis for acting and behaving. The formation of “Barenti Lako Syara' Tradition, Syara' Barenti Lako Kitabullah" as a way of life (traditional Law) is the result of the merging of adat and religion in harmony with the combination of "ratio" with "revelation" test.

The principle of 'Barenti Lako Syara' Tradition, Syara' Barenti Lako Kitabullah" has become a law for samawa. The Law in this principle means the accumulation of morals, ethics, customs, beliefs and habits. The morals that become the Law are satingi each other (mutual respect), pity each other (pedi each other), strengthen each other (sakiki each other), satotang each other (remind each other), $s a d u$ each other (trust each other), tulung each other (help each other), beme each other (protect each other). ${ }^{18}$ Acceptance of morals, ethics, customs, and habits becomes Law after being verified by religion, in this case the religion of Islam as revealed by Idrus Abdullah, Sumbawa figures that if there is a conflict between religion and custom then adat must be changed and accommodate it in the Islamic teaching principles. ${ }^{19}$

${ }^{17}$ R.M. Dworkin, Filsafat Hukum, Suatu Pengantar, terj. Yudi Santoso, (Yogyakarta: Merkid Press, 2007), hal. ix

${ }^{18}$ Zulkarnaien, Tradisi dan adat istiadat samawa. Yogyakarta. 2011. Penerbit. Ombak. hal. 20-21

19 Idrus Abdullah, Penyelesaian sengketa Bisnis di luar pengadilan antara warga suku Sasak di pulau lombok, Riset unggulan Kerjasama dengan Kementerian Riset dan Teknologi RI hal, 5 
Examining moral boundaries in Law according to the principle of "Barenti Lako Syara' Tradition, Syara' Barenti Lako Kitabullah” must be understood that in "tradition" there is a moral that becomes a cultural identity and in syara' there is a moral value that becomes a spiritual identity so that the combination of the two becomes Law for Tau Samawa. The word "barenti lako" means "make a basis, a beachhead" so that moral indicators in Law depend on whether or not customary Law is accepted by syara', likewise the moral indicators that exist in "syara" depends on whether or not the moral syara' is accepted by the Book of Allah. Syara' becomes a verification tool for morals in Tau Samawa customary law, and the book of Allah becomes the moral detector in syara'.

\section{CONCLUSION}

Von Savigny emphasized his guidance, that Law is a natural, innate not constituted, creation, but grows by itself. He considered that on this earth, there are many districts that have different volumes so that the Law only applies within the district based on time and place. Savigny's affirmation that in each nation there is a volkgeist, which in the context of Indonesia consists of many ethnic groups that have different customs, cultures, morals, shows that morality in Law depends on the prevailing morale in society and its moral form is not limited good and bad, wrong and right, halal and haram.

Moral restrictions in Law according to the concept of "Barenti Lako Syara' Tradition, Syara' Barenti Lako Kitabullah" Moral law restrictions in Law according to the concept of "tradition" Law must be understood that in "tradition" there is a moral that becomes a cultural identity and in syara' there is a moral value that becomes an spiritual identity so that the meeting of the two becomes Law for Tau Samawa. The word "barenti lako" means "to make a basis, a beachhead" so that moral indicators in Law depend on whether or not customary Law is accepted by syara', as well as moral indicators that exist in syara' whether or not the morality of syara' is accepted by the book of Allah. Syara' becomes a verification tool for morals in the Tau Samawa customary law and the book of Allah becomes the moral detector in syara'. 


\section{REFERENCES}

Abdullah, Idrus, Penyelesaian sengketa Bisnis di luar pengadilan antara warga suku Sasak di pulau lombok, Riset unggulan Kerjasama dengan Kementerian Riset dan Teknologi RI. 2015 (Business out-of-court dispute resolution between Sasak tribes on Lombok island, Leading Research Collaboration with the Indonesian Ministry of Research and Technology. 2015)

Absori dkk, Makna Pengelolaan Lingkungan Pespektif Etik Profetik (The Meaning of Environmental Management Perspective of Prophetic Ethics), Al-Tahrir, Vol. 17, No. 2 November 2017

Aries, Zulkarnaien, Tradisi dan adat istiadat samawa (Samawa traditions and customs). Yogyakarta. 2011. Publisher. Ombak.

Cahyade, Antonins . HUKUM RAKYAT Ii La Friedrich Karl von Savignyl JurnaJ Hukum dan Pembangunan, Tahun Ke-35 No.4 Oktober-Desember 2005 (PEOPLE'S LAW Ii La Friedrich Karl von Savigny Journal of Law and Development, Year 35 No.4 OctoberDecember 2005).

Cahyadi, Antonius dan Fernando M. Manullang, Pengantar Filsafat Hukum (Introduction to Legal Philosophy), 2010;

Dianto, Kewenangan Kepala Daerah Menerbitkan Izin Usaha Perkebunan Di Hutan Adat, Jurnal IUS | Vol III | Nomor 8 | Agustus; 2015 (Authority of Regional Head Issuing Plantation Business Permit in Indigenous Forests, IUS Journal | Vol III | Number 8 | August; 2015)

Dianto, Pola Penyelesaian Konflik Rekognisi Hak Masyarakat Adat Di Kabupaten Sumbawa Equilibrium: Jurnal Pendidikan Vol. VIII. Issu 1. Januari-Juni 2020. (Pattern of Settlement of Conflict Recognition of Indigenous Rights in Sumbawa Regency Equilibrium: Journal of Education Vol. VIII. Issues 1. January-June 2020.)

Dimyanti, Khuzaifah, Absori, kelik Wardiono, Fitrah Hamdani, : Morality anda law: Critics Upan H.L.A Hart'S Moral Paradigm Epistemology Basis based on Prophetic Paradigm. Jurnal Dinamika Hukum. Volume 7 Nomor 1 Tahun Januari 2017 (Morality anda law: Critics Upan H.L.A Hart'S Moral Paradigm Epistemology Basis based on Prophetic Paradigm. Journal of Legal Dynamics. Volume 7 Nomor 1 Tahun Januari 2017)

Dwi Putro, Widodo, Perselisihan Sociological Jurisprudence dengan Mazhab Sejarah dalam Kasus "MERARIK" Kajian Putusan Nomor 232/Pid.B/2008/PN.Pra , Jurnal Yudisial Vol. 6 No. 1 April 2013. (Sociological Jurisprudence Disputes with Historical Guidance in the "MERARIK" Case Study of Decision Number 232 / Pid.B / 2008 / PN.Pra, Judicial Journal Vol. 6 No. April 1, 2013.)

Dworkin, R.M., Filsafat Hukum, Suatu Pengantar (Legal Philosophy, An Introduction), terj. Yudi Santoso, (Yogyakarta: Merkid Press, 2007

Freeman, MDA Llyod 2001. Introduction to Jurisprudence. London: Sweet Maxwell. 2001

Iskandar, Syaifuddin, Konflik Etnis samawa dengan etnis Bali dalam konstruksi sosial masyarakat sumbawa. Disertasi. 2013. (The ethnic conflict between Samawa and the ethnic Balinese in the social construction of the Sumbawa community. Dissertation. 2013.) 
Hamdani, Fitrah, PARADIGMA PROFETIK: Antara Konsep Moralitas Piagam Madinah dan Konsep Moralitas Hukum H.L.A. Hart. Jurisprudence, Vol. 6 No. 1 Maret 2016 (PROFETICAL PARADIGM: Between the Morality Concept of the Medina Charter and the Concept of the Morality of Law H.L.A. Hart Jurisprudence, Vol. 6 No. March 1, 2016)

Lovell, T (ed.). (Mis)recognition, Social Inequality and Social Justice: Nancy Fraser and Pierre Bourdieu. London and NewYork: Routledge. Lovell, 2007

Tamanaha, Brian Z,. 2006. A General Jurisprudence for Law and Society. New York: Oxford University Press.

Wahid, Abdul et al, Etika Profesi hukum dan Nuansa Tantangan Profesi Hukum Di Indonesia, Panduan Bagi: Penasehat Hukum, Hakim, Jaksa, Polisi, dan Mahasiswa Fakultas hukum, Penerbit:Tarsita Bandung, 1999. (The Legal Professional Ethics And Nuances of The Challenges of The Legal Profession in Indonesia, A Guide for: Legal Advisors, Judges, Prosecutors, Police, and Law School College Students, Publisher: Tarsita Bandung, 1999.) 